\title{
High Prevalence of icaABCD Genes Responsible for Biofilm Formation in Clinical Isolates of Staphylococcus aureus From Hospitalized Children
}

\author{
Abdolmajid Ghasemian ${ }^{1}$; Shahin Najar-Peerayeh ${ }^{1, *}$; Bita Bakhshi ${ }^{1}$; Mohsen Mirzaee ${ }^{2}$ \\ ${ }^{1}$ Department of Bacteriology, Tarbiat Modares University, Tehran, IR Iran \\ ${ }^{2}$ Department of Laboratory Sciences, Borujerd Branch, Islamic Azad University, Borujerd, IR Iran \\ ${ }^{*}$ Corresponding author: Shahin Najar Peerayeh, Department of Bacteriology, Tarbiat Modares University, Tehran, IR Iran. Tel: +98-92182883870, E-mail: najarp_s@modares.ac.ir \\ Received: May 26, 2014; Revised: July 7, 2014; Accepted: May 13, 2015
}

\begin{abstract}
Background:The icaABCD genes encode a Polysaccharide Intercellular Adhesion (PIA), which is a tight structure protecting Staphylococcus aureus community against adverse environmental conditions. The $i c a$ dependent biofilm formation plays an important role in persistent infections in hospitalized patients.

Objectives: The aim of this study was to detect $i c a A D B C$ genes encoding PIA among S. aureus isolates from children in Loghman Hospital of Tehran.

Materials and Methods: We collected 22 clinical specimens from hospitalized pediatrics and identified the isolates. Then, we detected mecA gene among Methicillin Resistant S. aureus (MRSA), SCCmec types and icaABCD gens by PCR assay and specific primers.

Results: Five isolates (22.7\%) were methicillin resistant (MRSA) and mecA gene was detected among them. All the MRSA isolates harbored SCCmec type III. Prevalence of $i c a A, i c a B$, icaC and icaD in the isolates were 16 (73\%), 14 (63.6\%), 16 (73\%) and 16 (73\%), respectively. Moreover, all the MRSA strains were $i c a A D B C$ positive.

Conclusions: Prevalence of $i$ caADBC genes was relatively high among children and also all the four ica genes were detected among MRSA strains.
\end{abstract}

Keywords: Staphylococcus aureus; MRSA; Biofilms; Pediatrics

\section{Background}

S. aureus clinical isolates, especially methicillin resistant strains, are the causative agents of various clinical signs such as folliculitis, boils, impetigo and cellulitis, which are important in children $(1,2)$. S. aureus infections have been sharply increased during the recent years and associated with more mortality than other bacterial agents (3). Attachment and colonization is the first step for Staphylococcus aureus pathogenesis. Biofilm formation leads to bacterial resistance to higher concentrations of antimicrobial agents in addition to host immune responses (4). The self-produced polymeric matrices adhere to inert and living surfaces (5). Penetration of antibiotics reduces through S. aureus and S. epidermidis biofilms (6), although carbon and amino acids can be adsorbed by the biofilm layers (7). Some of special clonal complexes (e.g. clonal complex 8) are capable to adhere to different surfaces and produce a large amount of biofilm (8). The icaADBC genes, encoding PIA play important roles in biofilm formation among S. aureus and S. epidermidis isolates (9). Infections caused by isolates producing slime layer are difficult to treat. Many chronic infections due to S. aureus, especially through medical devices, are associated with biofilm formation $(10,11)$. Strong biofilm producer isolates are more virulent with severe post-surgical infec- tions (12). The ica dependent biofilm formation develops by production of a polysaccharide inter cellular adhesion (PIA- PNSG/ poly- beta-1, 6-N-acetylglucosamine polymer) by the N-acetyl glucose aminyl transferase enzyme (13). Two ica $A$ and $D$ genes in the operon encode this enzyme. The other genes in this operon include icaB (polysaccharide deacetylase), icaC (transporter of PIA) and icaR (the regulatory gene). In Akiyama's study, all S. aureus strains tested in skin lesions of impetigo, atopic dermatitis and pemphigus were covered with glycocalyx and formed microcolonies (14). Systemic and intravenous Staphylococcal isolates have been shown to harbor ica genes as twice as the normal flora of healthy volunteers (13). Most reports have detected some of these genes.

\section{Objectives}

The aim of this study was to detect the icaADBC genes encoding PIA among clinical isolates of S. aureus from children in Loghman Hospital of Tehran.

\section{Materials and Methods}

We collected 22 S. aureus isolates and then identified them with coagulase, manitol fermentation, colony mor- 
Ghasemian A et al.

phology and DNase tests. Methicillin resistant isolates were identified in the phenotypic test by disk diffusion with oxacillin disk. Bacterial isolates were suspended in $200 \mu \mathrm{L}$ of TE buffer and then lysostaphin was added (comprising $200 \mu \mathrm{L}$ of TE buffer and $20 \mu \mathrm{L}$ of lysostaphin [2 $\mu \mathrm{g} /$ $\mathrm{mL}$, Sigma]). Genomic DNA of S. aureus isolates was isolated according to Straubinger method (15). The mecA gene was detected with specific primers indicated in Table 1 (16). PCR reaction mixture comprised of $9.5 \mu \mathrm{L}$ distilled water (DW), $2 \mu \mathrm{L}$ DNTPs (10 mM), $1.5 \mu \mathrm{L} \mathrm{MgCl} 2$ (50 mM), 1 $\mu \mathrm{L}$ of each primer, $3 \mu \mathrm{L}$ 10X PCR buffer ( $200 \mathrm{mM}), 2 \mu \mathrm{L}$ Taq polymerase ( $500 \mathrm{U}$ ) and $5 \mu \mathrm{L}$ template DNA. The thermal profile included initial denaturation at $94^{\circ} \mathrm{C}$ for $5 \mathrm{~min}$, followed by 30 cycles of $94^{\circ} \mathrm{C}(30 \mathrm{~s}), 55^{\circ} \mathrm{C}(30 \mathrm{~s})$ and $72^{\circ} \mathrm{C}$ (30 s) and final extension of $72^{\circ} \mathrm{C}(4 \mathrm{~min})$. Reaction mixture for SCCmec types was $94^{\circ} \mathrm{C}(1 \mathrm{~min}), 51^{\circ} \mathrm{C}(1 \mathrm{~min}), 72^{\circ} \mathrm{C}$ (1.5 min) and final extension of $72^{\circ} \mathrm{C}$ for $10 \mathrm{~min}$. Moreover, thermal profile for icaA gene concluded with $94^{\circ} \mathrm{C}(5$ min), followed by 30 cycle of $94^{\circ} \mathrm{C}(1 \mathrm{~min}), 52^{\circ} \mathrm{C}(30 \mathrm{~s})$ and $72^{\circ} \mathrm{C}(1.5 \mathrm{~min})$ with final extension of $72^{\circ} \mathrm{C}(10 \mathrm{~min})$. The annealing temperature for icaB, icaC and icaD set as $55^{\circ} \mathrm{C}$ for 1 min (17), shown in Table 2. PCR products were electrophoresed in $1 \%$ gel agarose in $1 \mathrm{X}$ TBE buffer with staining of $1 \mu \mathrm{L}$ of each loading buffer and gel red and then observed under UV emission. Pearson Chi-Square was used to data analysis. A P $<0.05$ considered significant.

\begin{tabular}{|c|c|c|c|}
\hline Primer & Sequence 5' $\rightarrow$ 3' & Size (bp) & Reference \\
\hline \multirow[t]{3}{*}{$\operatorname{mec} A$} & & 147 & (16) \\
\hline & AAG ATA TAC CAA GTG ATT & & \\
\hline & CGC TATAGATTGAAA GGA & & \\
\hline \multirow[t]{3}{*}{ SCCmecI } & & 613 & (16) \\
\hline & TAAAGAGTGTCGTTACAGG & & \\
\hline & CTCTCATAGTATGACGTCC & & \\
\hline \multirow[t]{3}{*}{ SCCmecII } & & 398 & (16) \\
\hline & ITTGAAGATGATGAAGCG & & \\
\hline & AATCAATGGTTAATGGACC & & \\
\hline \multirow[t]{3}{*}{ SCCmecIII } & & 280 & (16) \\
\hline & CATATTGTGTACGATGCG & & \\
\hline & TAGTTGTCGTAACAGATCG & & \\
\hline \multirow[t]{3}{*}{ SCCmecIVa } & & 776 & (16) \\
\hline & CCTTATTCGAAGAAACCG & & \\
\hline & ACTCTTCTGAAAAGCGTCG & & \\
\hline \multirow[t]{3}{*}{ SCCmecV } & & 325 & (16) \\
\hline & CATTGTTACTTAAATGAGCG & & \\
\hline & AAGTTGTACCCTTGACACC & & \\
\hline
\end{tabular}

\begin{tabular}{|c|c|c|c|}
\hline Primer & Sequence 5' $\rightarrow$ 3' & Size (bp) & Reference \\
\hline \multirow[t]{3}{*}{ icaA } & & 188 & (17) \\
\hline & F: ACACTTGCTGGCGCAGTCAA & & \\
\hline & R: TCTGGAACCAACATCCAACA & & \\
\hline \multirow[t]{3}{*}{ icaB } & & 900 & (17) \\
\hline & F: AGAATCGTGAAGTATAGAAAATT & & \\
\hline & R:TCTAATCTTTTTCATGGAATCCGT & & \\
\hline \multirow[t]{3}{*}{ icaC } & & 1100 & (17) \\
\hline & F:ATGGGACGGATTCCATGAAAAAGA & & \\
\hline & R:TAATAAGCATTAATGTTCAATT & & \\
\hline \multirow[t]{3}{*}{$i c a D$} & & 198 & (17) \\
\hline & F: ATGGTCAAGCCCAGACAGAG & & \\
\hline & R: AGTATTTTCAATGTTTAAAGCAA & & \\
\hline
\end{tabular}


Ghasemian A et al.

\begin{tabular}{lccccc}
\hline \multicolumn{1}{l}{ Table 3. Characteristics of MRSA Isolated From Hospitalized Children } & & & \\
\hline MRSA & Clinical Origin & mecA & SCCmec & ica Genes & Gender \\
\hline $\mathbf{1}$ & Trachea & + & III & ADBC & Male \\
$\mathbf{2}$ & Blood & + & III & ADBC & Male \\
$\mathbf{3}$ & Lesion & + & III & ADBC & Female \\
$\mathbf{4}$ & Trachea & + & III & ADBC & Male \\
$\mathbf{5}$ & Lesion & + & III & ADBC & Male \\
\hline
\end{tabular}

Figure 1. PCR Products Amplified in This Study

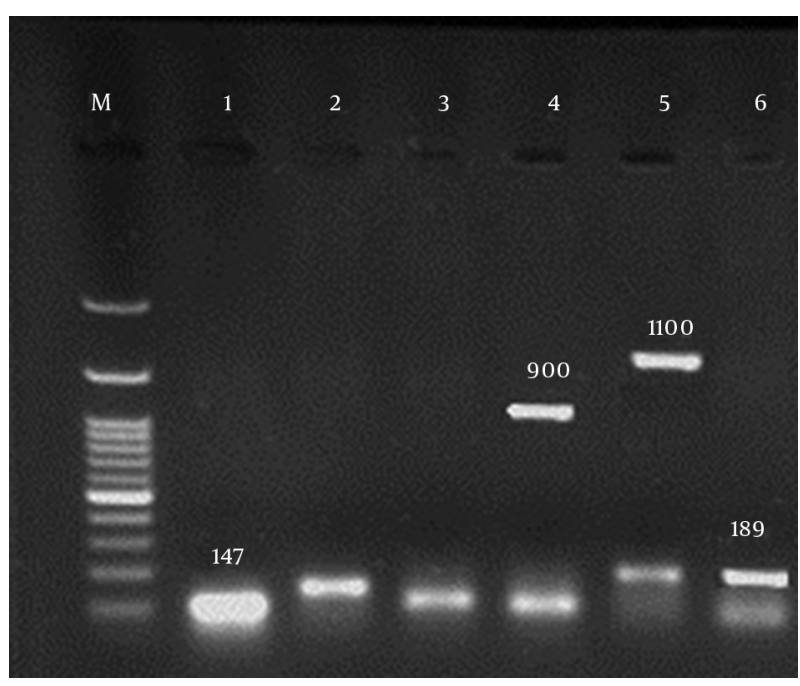

M: marker. columns 1, 3 and 4: mecA gene. column 2: icaA with 188 bp. columns 5 and 6: icaD gene with $189 \mathrm{bp}$. columns 4 and 5: icaB and icaC with 900 and $1100 \mathrm{bps}$, respectively.

\section{Results}

Five $(22.7 \%)$ isolates were resistant to oxacillin $(1 \mu \mathrm{g})$, moreover all the isolates were susceptible to vancomycin $(2 \mu \mathrm{g})$ and linezolid $(30 \mu \mathrm{g})$ disks. The mecA gene was detected in all five isolates (22.7\%) with $147 \mathrm{bp}$ size. All the MRSA isolates harbored SCCmec type III.

Furthermore, the prevalence of icaA, $B, C$ and $D$ in the isolates were 16 (73\%), 14 (63.7\%), 16 (73\%) and 16 (73\%), respectively as depicted in Figure 1. Interestingly, all MRSA isolates harbored all of $i c a A D B C$ genes, suggesting that MRSA isolates may be more capable of PIA synthesis and biofilm formation (Table 3). However, there was no significant difference between MRSA and MSSA strains for the presence of $i c a A D B C$ operon.

\section{Discussion}

All the studied isolates were susceptible to vancomycin and linezolid; although these drugs are the last choices for treatment of $S$. aureus infections, resistance to vancomycin has been sporadically reported from some areas of the world, similar to Iran $(18,19)$. Moreover, resistance to linezolid was detected in 19 of 20 isolates studied by Armin et al. (20). In this study, all MRSA strains harbored SCCmec type III. In the study of Japoni et al. (21) from south of Iran, SCCmec type III was the predominant type. MRSA strains harbor several virulence factors that develop more clinical signs $(17,22)$. Also the study by Imani Fouladi et al. (22), 75\% of Staphylococcus aureus isolates with the SEB gene were Methicillin resistant and $15 \%$ were MSSA. In the study of Rahimi et al. (23), all the isolates were susceptible to vancomycin and most were susceptible to SXT. MRSA isolates harbored all icaADBC genes, suggesting that these isolates are strong biofilm producers and considered to cause chronic and persistent infections (24). Polymeric Intercellular Adhesion (PIA) plays an important role in attachment of bacteria to each other and to accumulate with multilayered biofilm. Catheter and blood stream Staphylococcal infections play an important role in biofilms $(25,26)$. We confirmed no significant difference between MSSA and MRSA isolates of $S$. aureus regarding the presence of icaADBC genes, similar to survey Atshan et al. (27), in which icaADBC genes were compared between MRSA and MSSA. Furthermore, we previously observed that most isolates belonged to accessory gene regulator (agr) group I (28), but the relationship of agr groups and icaADBC expression needs more studies. Several studies indicated the role of $i c a A$ and icaD genes in biofilm production and several reported that all of isolates were icaA positive (29). In the study by Hou et al. (30), among $55.56 \%$ of isolates that produced biofilm phenotypically, $11.11 \%$ had $i c a A$ gene, but other genes were not investigated. In this study, methicillin resistant isolates harbored higher rate of $i c a A D B C$ genes, similar to studies conducted by Khan et al. (31) and O'neill et al. (32). However, Smith et al. (33) detected no significant correlation between susceptibility to methicillin and biofilm formation. Variations in the presence of $i c a A D B C$ genes from studies might be due to epidemiological varieties and periods that these isolates have been collected.

Most of previous studies focused on the $i c a A D$ genes that encode PIA; likewise, these studies have not determined whether MRSA strains could produce PIA significantly more than MSSA isolates. For instance, Nasr et al. (34) detected $i c a A D$ genes in $32 \%$ of blood and catheter isolates. In the other study, 36 of 46 Staphylococcal isolates harbored icaA and icaD genes; while Grinholc and coworkers did not detect icaD, but all strains were icaA 
positive (35). Terki et al. (36) detected icaAD genes in 17 (38.5\%) of 44 staphylococcal isolates from urinary tract. In the other study, biofilm formation in most isolates was PIA dependent (37). Smith et al. (33) depicted that isolates of $S$. aureus from infected skin lesions were significantly more capable of producing biofilms than those isolated from blood and other infected sites. In the study of Semczuk et al. (38), all the isolates forming biofilm phenotypically, harbored icaAD genes. Satorres and Alcaraz (13) suggested that the ica genes might be more prevalent in Staphylococcus strains isolated from hospitalized patients or staff, than healthy individuals or the community. The limitations of this study were loss of healthy individuals, environmental strains and low number of isolates. In conclusion, the prevalence of $i c a A D B C$ genes was high in hospitalized children in center of Tehran. There was no significant difference between MRSA and MSSA isolates of $S$. aureus regarding the presence of icaADBC genes, although all methicillin resistant strains harbored all the icaADBC genes.

\section{Acknowledgements}

The authors acknowledge the staff of the Laboratory of Loghman Hospital of Tehran for providing clinical isolates. This study was obtained from a thesis of Master of Sciences in Faculty of Medical Sciences, Tarbiat Modares University, Tehran, IR Iran.

\section{Authors' Contributions}

Abdolmajid Ghasemian followed the microbiological and molecular laboratory studies. Shahin Najar Peerayeh designed the thesis of research, Bita Bakhshi and Mohsen Mirzaee advised the research.

\section{Funding/Support}

This work was supported by grants for a thesis from Faculty of Medical Sciences of Tarbiat Modares University, Tehran, IR Iran.

\section{References}

1. Nkwelang G, Akoachere JFT, Kamga LH, Nfoncham ED, Ndip RN. Staphylococcus aureus isolates from clinical and environmental samples in a semi-rural area of Cameroon: phenotypic characterization of isolates. Afri J Microbiol Res. 2009;3(11):731-6.

2. Post V, Wahl P, Uckay I, Ochsner P, Zimmerli W, Corvec S, et al. Phenotypic and genotypic characterisation of Staphylococcus aureus causing musculoskeletal infections. Int J Med Microbiol. 2014;304(5-6):565-76.

3. Naber CK. Staphylococcus aureus bacteremia: epidemiology, pathophysiology, and management strategies. Clin Infect Dis. 2009;48 Suppl 4:S231-7.

4. Verma P, Maheshwari SK, Mathur A. A review on bacterial biofilm formation and disassembly. Int J Pharm Sci Res. 2013;4(8):2900-6.

5. Diemond-Hernandez B, Solorzano-Santos F, Leanos-Miranda B, Peregrino-Bejarano L, Miranda-Novales G. Production of icaADBC-encoded polysaccharide intercellular adhesin and therapeutic failure in pediatric patients with Staphylococcal devicerelated infections. BMC Infect Dis. 2010;10:68.

6. Nathan KA, Mark JMJ, William C. Staphylococcus aureus biofilms. Vir. 2011;2(5):1-15.
7. Zhu Y, Weiss EC, Otto M, Fey PD, Smeltzer MS, Somerville GA. Staphylococcus aureus biofilm metabolism and the influence of arginine on polysaccharide intercellular adhesin synthesis, biofilm formation, and pathogenesis. Infect Immun. 2007;75(9):4219-26.

8. Croes S, Deurenberg RH, Boumans ML, Beisser PS, Neef C, Stobberingh EE. Staphylococcus aureus biofilm formation at the physiologic glucose concentration depends on the S. aureus lineage. BMC Microbiol. 2009;9:229.

9. Eftekhar F, Dadaei T. Biofilm formation and detection of icaAB genes in clinical isolates of methicillin resistant staphylococcus aureus. Iran J Basic Med Sci. 2011;14(2):132-6.

10. Martin-Lopez JV, Perez-Roth E, Claverie-Martin F, Diez Gil O, Batista N, Morales M, et al. Detection of Staphylococcus aureus Clinical Isolates Harboring the ica Gene Cluster Needed for Biofilm Establishment.J Clin Microbiol. 2002;40(4):1569-70.

11. Glinska K, Tkacikova L. Detection of icaA gene encoding the biofilm formation in S.aureus isolates. Folia Veterinaria. 2009;53(1):10-1.

12. Bekir K, Haddad O, Grissa M, Chaieb K, Bakhrouf A, Elgarssdi SI Molecular detection of adhesins genes and biofilm formation in methicillin resistant Staphylococcus aureus. African J Microbio Res. 2012;6(23):4908-17.

13. Satorres SE, Alcaraz LE. Prevalence of icaA and icaD genes in Staphylococcus aureus and Staphylococcus epidermidis strains isolated from patients and hospital staff. Central Eur I Public Health. 2007;15(2):87-90.

14. Akiyama H, Hamada T, Huh WK, Yamasaki O, Oono T, Fujimoto $\mathrm{W}$, et al. Confocal laser scanning microscopic observation of glycocalyx production by Staphylococcus aureus in skin lesions of bullous impetigo, atopic dermatitis and pemphigus foliaceus. $B$ J Dermatol. 2003;148(3):526-32.

15. Gey A, Werckenthin C, Poppert S, Straubinger RK. Identification of pathogens in mastitis milk samples with fluorescent in situ hybridization. J Vet Diagn Invest. 2013;25(3):386-94.

16. Zhang K, Sparling J, Chow BL, Elsayed S, Hussain Z, Church DL, et al. New quadriplex PCR assay for detection of methicillin and mupirocin resistance and simultaneous discrimination of Staphylococcus aureus from coagulase-negative staphylococci. $J$ Clin Microbiol. 2004;42(11):4947-55.

17. Hoseini Alfatemi SM, Motamedifar M, Hadi N, Sedigh Ebrahim Saraie H. Analysis of Virulence Genes Among Methicillin Resistant Staphylococcus aureus (MRSA) Strains. Jundishapur J Microbiol. 2014;7(6):e10741.

18. Howden BP, Davies JK, Johnson PD, Stinear TP, Grayson ML. Reduced vancomycin susceptibility in Staphylococcus aureus, including vancomycin-intermediate and heterogeneous vancomycin-intermediate strains: resistance mechanisms, laboratory detection, and clinical implications. Clin Microbiol Rev 2010;23(1):99-139.

19. Azimian A, Havaei SA, Fazeli H, Naderi M, Ghazvini K, Samiee SM et al. Genetic characterization of a vancomycin-resistant Staphylococcus aureus isolate from the respiratory tract of a patient in a university hospital in northeastern Iran. J Clin Microbiol. 2012;50(11):3581-5.

20. Armin S, Rouhipour A, Fallah F, Rahbar M, Ebrahimi M. Vancomycin and linezolid resistant staphylococcus in hospitalized children. Arch Pediatr Infect Dis. 2012;1(1):4-8.

21. Japoni A, Jamalidoust M, Farshad S, Ziyaeyan M, Alborzi A, Japoni $S$, et al. Characterization of SCCmec types and antibacterial susceptibility patterns of methicillin-resistant Staphylococcus aureus in Southern Iran. Jpn JInfect Dis. 2011;64(1):28-33.

22. Imani Fouladi AA, Choupani A, Fallah Mehrabadi J. Study of prevalence of Enterotoxin type B gene in Meticillin Resistant Staphylococcus aureus (MRSA) isolated from wound. KowsarMed J. 2011;16(1):21-5.

23. Rahimi F, Bouzari M, Maleki Z, Rahimi F. Antibiotic susceptibility pattern among Staphylococcus spp. with emphasis on detection of mecA gene in methicillin resistant Staphylococcus aureus isolates. Arch Clin Infect Dis. 2009;4(3):143-50.

24. Begun J, Gaiani JM, Rohde H, Mack D, Calderwood SB, Ausubel FM, et al. Staphylococcal biofilm exopolysaccharide protects against Caenorhabditis elegans immune defenses. PLoS Pathog. 2007;3(4):e57. 


\section{Ghasemian A et al.}

25. O'Gara JP. ica and beyond: biofilm mechanisms and regulation in Staphylococcus epidermidis and Staphylococcus aureus. FEMS Microbiol Lett. 2007;270(2):179-88.

26. Ziebuhr W, Heilmann C, Gotz F, Meyer P, Wilms K, Straube E, et al. Detection of the intercellular adhesion gene cluster (ica) and phase variation in Staphylococcus epidermidis blood culture strains and mucosal isolates. Infect Immun. 1997;65(3):890-6.

27. Atshan SS, Nor Shamsudin M, Sekawi Z, Lung LT, Hamat RA, Karunanidhi A, et al. Prevalence of adhesion and regulation of biofilm-related genes in different clones of Staphylococcus aureus.J Biomed Biotechnol. 2012;2012:976972.

28. Ghasemian A, Peerayeh SN, Bakhshi B, Mirzaee M. Accessory Gene Regulator Specificity Groups Among Staphylococcus aureus Isolated From Hospitalized Children. Arch Pediatr. 2014;2(2):e16096.

29. Yazdani R, Oshaghi M, Havayi A, Pishva E, Salehi R, Sadeghizadeh $\mathrm{M}$, et al. Detection of icaAD gene and biofilm formation in Staphylococcus aureus isolates from wound infections. Iran J Public Health. 2006;35(2):25-8.

30. Hou W, Sun X, Wang Z, Zhang Y. Biofilm-forming capacity of Staphylococcus epidermidis, Staphylococcus aureus, and Pseudomonas aeruginosa from ocular infections. Invest Ophthalmol Vis Sci. 2012;53(9):5624-31.

31. Khan F, Shukla I, Rizvi M, Mansoor T, Sharma SC. Detection of Biofilm Formation in Staphylococcus aureus. Does it have a Role in Treatment of MRSA Infections? Trends Med Res. 2011;6(2).
32. O'Neill E, Pozzi C, Houston P, Smyth D, Humphreys H, Robinson $\mathrm{DA}$, et al. Association between methicillin susceptibility and biofilm regulation in Staphylococcus aureus isolates from devicerelated infections. J Clin Microbiol. 2007;45(5):1379-88.

33. Smith K, Perez A, Ramage G, Lappin D, Gemmell CG, Lang S. Biofilm formation by Scottish clinical isolates of Staphylococcus aureus.J Med Microbiol. 2008;57(Pt 8):1018-23.

34. Nasr RA, AbuShady HM, Hussein HS. Biofilm formation and presence of icaAD gene in clinical isolates of staphylococci. Egypt $J$ Med Human Genetics. 2012;13(3):269-74.

35. Szweda P, Schielmann M, Milewski S, Frankowska A, Jakubczak A. Biofilm production and presence of ica and bap genes in Staphylococcus aureus strains isolated from cows with mastitis in the eastern Poland. Pol J Microbiol. 2012;61(1):65-9.

36. Terki IK, Hassaine H, Oufrid S, Bellifa S, Mhamedi I, Lachachi M, et al. Detection of icaA and icaD genes and biofilmformation in Staphylococcus spp. isolated from urinary catheters at the University Hospital of Tlemcen (Algeria). African J Microbiol Res. 2013;7(47):5350-7.

37. Otto M. Staphylococcal biofilms. Curr Top Microbiol Immunol. 2008;322:207-28.

38. Semczuk K, Dzierzanowska-Fangrat K, Dmenska H, Dzierzanowska D. [The analyze of capability of biofilm synthesis by Staphylococcus aureus strains isolated from children with cystic fibrosis]. Med Dosw Mikrobiol. 2008;60(4):311-8. 